\title{
Neurologic Complications of Metronidazole
}

\author{
Justyna R. Sarna, Sarah Furtado, A. Keith W. Brownell
}

\begin{abstract}
Metronidazole (Flagyl@) is an antimicrobial agent commonly used in clinical practice. Although it is generally well tolerated with minimal side effects, there are a host of still under-recognized neurologic complications of metronidazole treatment. The following review is aimed at summarizing current literature pertaining to metronidazole-induced neurotoxicity including clinical syndromes, neuroradiological findings, prognosis and proposed pathophysiology. Recognition of the neurotoxic effects of metronidazole is critical as prompt discontinuation is generally associated with full clinical recovery and radiological resolution.
\end{abstract}

\begin{abstract}
RÉSUMÉ: Complications neurologiques du métronidazole. Le métronidazole (Flagyl®) est un agent antimicrobien utilisé couramment en pratique clinique. Bien qu'il soit généralement bien toléré et que ses effets secondaires soient minimes, il existe une myriade de complications neurologiques du traitement par le métronidazole qui ne sont pas toujours reconnues. Le but de cette revue constitue un sommaire de la littérature actuelle concernant la neurotoxicité induite par le métronidazole dont les syndromes cliniques, les constatations neuroradiologiques, le pronostic et l'hypothèse physiopathologique expliquant cette neurotoxicité. Il est important d'identifier ces effets neurotoxiques du métronidazole étant donné que l'arrêt immédiat du traitement est généralement associé à une guérison clinique complète et à la disparition des signes radiologiques.
\end{abstract}

Can J Neurol Sci. 2013; 40: 768-776

Metronidazole (Flagyl ${ }^{\circledR} ; 1$-( $(\beta$-hydroxy-ethyl)-2-methyl-5nitroimidazole) is an antiprotozoal and antimicrobial agent commonly used in clinical practice. It was first introduced in 1959 for the treatment of Trichomonas vaginalis ${ }^{1}$. Although metronidazole is usually well tolerated, common side effects include metallic taste, nausea, vomiting, diarrhea, abdominal cramps, dark urine, headache, dizziness and disulfram-like reaction with exposure to alcohol ${ }^{1}$.

Metronidazole is primarily metabolized by the liver with peak serum levels of the drug (between 20 to $80 \mu \mathrm{g} / \mathrm{mL}$ ) achieved within one hour of oral administration of recommended doses of 1 to $2 \mathrm{~g} / \mathrm{day}^{2,3}$. It is a lipophilic compound that readily crosses the blood-brain barrier ${ }^{4}$, is renally excreted, and has a half life of approximately eight hours ${ }^{1}$.

Chronic metronidazole administration is not limited to the treatment of refractory infections - its use has become widespread in the context of a variety of clinical scenarios. The first is in the management of hepatic encephalopathy when treatment with lactulose alone is insufficient ${ }^{5}$. Second, metronidazole is used in the treatment of inflammatory bowel disease (IBD) as enteric flora are thought to contribute to its pathogenesis (e.g., $\left.{ }^{6}\right)$. Finally, and purely from a historical perspective, high doses of metronidazole were evaluated as a potentiating agent in radiotherapy but it was subsequently found to be ineffective ${ }^{7,8}$.

Metronidazole can be neurotoxic and produce a variety of neurologic syndromes including a cerebellar syndrome, encephalopathy, seizures, and optic, autonomic and peripheral neuropathies (Table 1). As many of the neurologic syndromes are fully reversible upon discontinuation of the drug, it is likely that metronidazole's neurotoxicity may not be recognized or reported. We previously described two cases with a cerebellar syndrome following prolonged exposure to metronidazole ${ }^{9}$. This

\begin{tabular}{l} 
Table 1: Known neurological side effects of metronidazole \\
(Adapted from ${ }^{9}$ ). \\
\hline Neurological side effects of metronidazole \\
\hline Cerebellar syndrome \\
\hline Encephalopathy \\
\hline Seizures \\
Optic neuropathy \\
Autonomic neuropathy \\
Peripheral neuropathy \\
\hline
\end{tabular}

From the Department of Clinical Neurosciences, Faculty of Medicine, University of Calgary, Calgary, Alberta, Canada.

Received March 15, 2013. Final Revisions Submitted June 26, 2013. Correspondence to: Justyna R. Sarna, Department of Clinical Neurosciences, Faculty of Medicine, University of Calgary, Calgary, Alberta, Canada.

Email: jrsarna@ucalgary.ca. 
Table 2: Summary of case reports of metronidazole-induced cerebellar syndrome.

\begin{tabular}{|c|c|c|c|c|c|c|}
\hline Reference & $\mathrm{n}$ & Age, Sex & Cumulative Dase (g) & Duration (d) & Resolution & Imaging \\
\hline Ahmed et al.. 1995 (11) & 1 & $45, \mathrm{~F}$ & $31.5 \mathrm{~g}$ & $30 \mathrm{~d}$ & $\begin{array}{l}\text { Resolution of symptoms within } 1 \text { week } \\
\text { (symptoms: confusion, alaxia, sensory } \\
\text { changes, vertigo, tinnitus, hearing loss) }\end{array}$ & $\begin{array}{l}\text { CT: nomal } \\
\text { T2 signal: DCN and supratentorial WM including CC. } \\
\text { (imaging almost nomalized within } 6 \text { weeks) }\end{array}$ \\
\hline Alvarez et al., 1983 (12) & 1 & $20, \mathrm{~F}$ & $25.5 g$ & $18 \mathrm{~d}$ & Symptoms resolved & $\mathrm{n} / \mathrm{a}$ \\
\hline Bonkowsky et al.. 2007 (13) & 1 & $27 . \mathrm{M}$ & $\mathrm{n} / \mathrm{a}$ & $14 d$ & $\begin{array}{l}\text { Resolution of symptoms within } 3 \text { weeks } \\
\text { (symptoms: confusioa, ataxia) }\end{array}$ & $\begin{array}{l}\text { DCN, dorsal pons and medulla: resolution in } 6 \mathrm{wks} \\
\text { (no enhancement) } 6 \mathrm{wk} \text { fru MRI: resolutiog }\end{array}$ \\
\hline Chatzkel and Vossough, 2010 (14) & 1 & $15, \mathrm{~F}$ & $\mathrm{~N} / \mathrm{a}$ & $7 \mathrm{~d}$ & $\begin{array}{l}\text { n/a } \\
\text { (clinical resolution nos discussed) }\end{array}$ & $\begin{array}{l}\text { T2/FLAIR hyperintensities within dentate buclei } \\
\text { f/u MRI: complete resolution }\end{array}$ \\
\hline De Bleecker et al., 2005 (15) & 1 & $20, \mathrm{M}$ & $1095 \mathrm{~g}$ & $2 \mathrm{yrs}$ & $\begin{array}{l}\text { (symptoms: sensory x } 1 \text { yr, ataxia } \times 2 \text { mo; } \\
\text { visual loss } \times 2 \text { wks) marked improvement } \\
\text { in vision and ataxia in } 2 \text { wks; sensory } \\
\text { symptoms resolved w/t } 3 \text { months }\end{array}$ & $\begin{array}{l}\text { MRI: T2/FL.AIR signal hyperintensities within the } \\
\text { splenium of the corpus callosum }\end{array}$ \\
\hline Deenadayalu et al., 2005 (16) & 1 & $50, \mathrm{M}$ & $7.5 \mathrm{~g}$ & $5 \mathrm{~d}$ & $\begin{array}{l}\text { Cerebellar syndrome only } 5 \text { days of tx } \\
\text { Pt had hepatic encephalopathy } \\
\text { Clinical improvement } 2 \text { wks post de }\end{array}$ & $\begin{array}{l}\text { CT: normal } \\
\text { MRI: symmetrical hyperintensities within the dentate } \\
\text { nuclei. f/u MRI: complete resolution }\end{array}$ \\
\hline Galvez et al.. 2009 (17) & 1 & $60, \mathrm{M}$ & $\mathrm{n} / \mathrm{a}$ & n/a & $\begin{array}{l}\text { Chronic liver disease (Hepatitis C) } \\
\text { Ataxia, myoclonus and worsening } \\
\text { encephalopsthy within days of increased } \\
\text { dose of metronidazole } \\
\text { Clinical improvement within I week }\end{array}$ & $\begin{array}{l}\text { MRI: symmetrical T2 hyperintensities within the dentate } \\
\text { nuclei, corpous callosum, inferior colliculi, caudal medulla } \\
\text { f/u MRI: complete resolution }\end{array}$ \\
\hline Graves et al.. 2009 (18) & 1 & $61, \mathrm{M}$ & $92.4 \mathrm{~g}$ & $77 \mathrm{~d}$ & $\begin{array}{l}\text { Multiple transplant patient } \\
\text { Toxic metronidazole level } \\
\text { Complete clinical resolution } 8 \text { wks later }\end{array}$ & $\begin{array}{l}\text { CT: normal } \\
\text { MRI: symmetrical T2/FLAIR hyperintensities }\end{array}$ \\
\hline Gupta, 2003 (19) & 1 & $50, \mathrm{M}$ & $200 \mathrm{~g}$ & $84 d$ & $\begin{array}{l}\text { Cerebellar syndrome and severe peripheral } \\
\text { neuropathy } \\
\text { Clinical improvement and resolution in } \\
\text { cerebellar syndrome but not neuropathy }\end{array}$ & CT: hypodense areas in the cerebellum \\
\hline Heaney et al., 2003 (20) & 1 & $74, \mathrm{M}$ & $75 g$ & $56 d$ & $\begin{array}{l}\text { Cerebellar syndrome and peripheral } \\
\text { neuropathy (lower extremitics only) }\end{array}$ & $\begin{array}{l}\text { CT: no acute changes (old lacunes) } \\
\text { MRI: T2/FLAIR hyperintensities w/t dentate noclei; } \\
\text { minimal T1 hypointensity; no gad enhancement; T2 shine- } \\
\text { through on ADC. F/U MRI at } 8 \text { wks: complete resolution } \\
\text { of signal changes }\end{array}$ \\
\hline Horlen et al., $2000(21)$ & 1 & $35, \mathrm{M}$ & $60 \mathrm{~g}$ & $55 \mathrm{~d}$ & $\begin{array}{l}\text { Pt with liver cirrhosis; developed cerebellar } \\
\text { syndrome and perripheral neuropanthy on } \\
\text { metronidazole treatment } \\
\text { Toxic metronidazole level } \\
\text { Resolution not reported }\end{array}$ & MRI: signal changes within the dentate \\
\hline Ito et al., $2004(22)$ & 1 & $54, \mathrm{~F}$ & $66 \mathrm{~g}$ & & $\begin{array}{l}\text { Cerebellar sybdrome } \\
\text { Resolution of symptoms within one week }\end{array}$ & $\begin{array}{l}\text { MRI: T2/FLAIR hyperintensities within the dentane } \\
\text { MRI at } 8 \text { days marked improvement } \\
\text { MRI at } 3 \text { months; complete resolution }\end{array}$ \\
\hline Kalia et al.. $2010(23)$ & 1 & $43, \mathrm{M}$ & $72 \mathrm{~g}$ & God & Cerebellar syndrome & $\begin{array}{l}\text { MRI: T2/FLAIR hyperintensities within the dentute, dorsal } \\
\text { pons and splenium of the corpus callosum; restricted } \\
\text { diffusion on DWI }\end{array}$ \\
\hline Kusumi et al., $1980(10)$ & 1 & $45, \mathrm{~F}$ & $84 g$ & $28 \mathrm{~d}$ & $\begin{array}{l}\text { Encephalopathy, cerebellar syndrome and } \\
\text { painful peripheral neuroparhy } \\
\text { Encephalopathy and cerebellar findings } \\
\text { resolved wit } 6 \text { days } \\
\text { F/U at } 7 \text { months: resolution of neuropathy }\end{array}$ & CT: normal \\
\hline Law ford and Sorrell, 1994 (24) & 1 & $30, \mathrm{M}$ & $21 \mathrm{~g}$ & $14 \mathrm{~d}$ & $\begin{array}{l}\text { Cerebellar syndrome } 1 \text { day after do } \\
\text { metronidazole. Resolution } 1 \text { month later } \\
\text { Another episode months later after only } 2 \\
\text { days of metronidazole - vertigo, unilateral } \\
\text { deafness and ataxia }\end{array}$ & CT: nocmal \\
\hline Moosa and Perkins, 2010 (25) & 1 & $52, \mathrm{M}$ & $37.5 \mathrm{~g}$ & $35 \mathrm{~d}$ & $\begin{array}{l}\text { Cerebellar syndrome } \\
\text { Complete resolution within } 2 \text { weeks of } d / c \\
\text { metronidazole }\end{array}$ & $\begin{array}{l}\text { MRI: T2/FLAIR hyperintensities (and mild T1 } \\
\text { hypointensities) within the dentate suclei, inferior olivary } \\
\text { nuclei, central tegmental tracts, dorsal medullar and pons. } \\
\text { No restricted diffusion or enhancement. }\end{array}$ \\
\hline Patel et al., 2008 (26) & 1 & $63, \mathrm{M}$ & $84 g$ & $42 \mathrm{~d}$ & $\begin{array}{l}\text { Cerebellar syndrome and ?mild peripheral } \\
\text { neuropathy }\end{array}$ & $\begin{array}{l}\text { MRI: T2/FL.AIR hyperintensities withint he dentate } \\
\text { f/u MRI at }\end{array}$ \\
\hline \multirow[t]{2}{*}{ Sarna et al., 2009 (9) } & 2 & $54, \mathrm{M}$ & $60 \mathrm{~g}$ & 6od & $\begin{array}{l}\text { Cerebellar syndrome, seizures and } \\
\text { peripheral neuropathy. Complete resolution } \\
\text { at } 3 \text { month follow-up }\end{array}$ & MRI: T2/FLAIR byperintensities within the dentate nuclei \\
\hline & & $72, \mathrm{~F}$ & $25 \mathrm{~g}$ & $21 d$ & $\begin{array}{l}\text { Cerebellar syndrome } \\
\text { Resolution wit weeks }\end{array}$ & $\begin{array}{l}\text { MRI: T2/FLAIR hyperintensities within dentate nuclei. } \\
\text { Resolution at follow-up MRI }\end{array}$ \\
\hline Takase et al., 20015 (27) & 1 & $69, \mathrm{M}$ & $75 \mathrm{~g}$ & $50 \mathrm{~d}$ & $\begin{array}{l}\text { Cerebellar syndrome (unilateral) and } \\
\text { peripheral neuropathy } \\
\text { Complete resolution at } 1 \text { month }\end{array}$ & $\begin{array}{l}\text { MRI: T2/FLAIR hyperintensities within the dentate nuclei; } \\
\text { more marked in left hemisphere } \\
\text { SPECT: reduced perfusion in left hemisphere } \\
\text { f/u MRI at I month: resolution }\end{array}$ \\
\hline Toumi et al., $2008(28)$ & 1 & $27, \mathrm{M}$ & $60 \mathrm{~g}$ & na & $\begin{array}{l}\text { Cerebellar syndrome and peripheral } \\
\text { neuropathy }\end{array}$ & $\begin{array}{l}\text { MRI: T2/FL.AIR hyperintensities within dentate nuclei } \\
\text { Resolution at follow-up MRI }\end{array}$ \\
\hline \multirow[t]{2}{*}{ Woodruff et al., 2002 (29) } & 2 & $62, \mathrm{M}$ & $60 \mathrm{~g}$ & $30 \mathrm{~d}$ & $\begin{array}{l}\text { Cerebellar syndrome } \\
\text { Complete resolution at } 5 \text { week follow-up }\end{array}$ & $\begin{array}{l}\text { MRI: T2/FLAIR hyperintensities within dentate nuclei } \\
\text { Resolution at follow-up MRI }\end{array}$ \\
\hline & & $74, \mathrm{M}$ & $42 g$ & $28 \mathrm{~d}$ & $\begin{array}{l}\text { Cerebellar syndrome } \\
\text { Improvement in } 2 \text { weeks }\end{array}$ & $\begin{array}{l}\text { MRI: T2/FLAIR hyperintensities within dentate nuclei. } \\
\text { Resolution at follow-up MRI }\end{array}$ \\
\hline
\end{tabular}

review is aimed at summarizing current literature pertaining to neurologic toxicity produced by this widely used antibiotic, including clinical syndromes, neuroradiological findings, prognosis and proposed pathophysiology. Case reports of metronidazole toxicity were identified through a PubMed search.

\section{Clinical Syndromes: 1. Cerebellar Syndrome}

The cerebellar syndrome induced by metronidazole was first described by Kusumi et al more than 30 years $\mathrm{ago}^{10}$. Their patient was a 45-year-old female who received a cumulative dose of $84 \mathrm{~g}$ of metronidazole over 28 days for the treatment of 
an anterior mediastinal abscess. She developed a global cerebellar syndrome as well as a painful peripheral neuropathy. Although the cerebellar syndrome resolved six days post discontinuation of antibiotic treatment, neuropathic symptoms persisted for four months ${ }^{10}$.

Since the initial description, there have been many similar case reports (summarized in Table $2 ;^{9-29}$ ). The cerebellar syndrome typically consists of dysarthria, gait and appendicular ataxia, nystagmus and saccadic pursuit. The ataxia is typically symmetrical save one case report ${ }^{27}$ which described a patient with more severe involvement on one side correlating with greater T2 hyperintensity within the dentate nucleus and lower blood perfusion ipsilaterally in the cerebellum. The cumulative dose in these various case reports ranges widely from $7.5 \mathrm{~g}^{16}$ to $1095 \mathrm{~g}^{15}$ suggesting individual patient vulnerability. Duration of treatment resulting in the cerebellar syndrome generally consists of at least one to two months (e.g., 9,11,20,23) although the syndrome can result from a shorter course of treatment ${ }^{16}$. No obvious risk factors have been identified other than pre-existing hepatic encephalopathy with end-stage liver cirrhosis ${ }^{16}$. Systemic clearance of metronidazole was shown to be reduced in patients with hepatic dysfunction ${ }^{30}$ and Horlen et $\mathrm{al}^{21}$ also implicated this as a contributing cause in their description of a cerebellar syndrome in a patient with liver cirrhosis.

With metronidazole discontinuation, recovery is gradual and fully reversible within days (e.g., ${ }^{10}$ ) to weeks (e.g., ${ }^{13,18,27}$ ) .

Computed tomogram (CT) head in patients with this cerebellar syndrome is typically normal except for one case report describing cerebellar hypodensities ${ }^{19}$. Typical magnetic resonance (MR) changes in this same group of patients show characteristic bilateral symmetric T2/FLAIR hyperintensities within the dentate nuclei with no mass effect or enhancement (e.g., ${ }^{9}$ ). These radiological features resolve with drug discontinuation and parallel clinical recovery.

Approximately one third of the described patients with a metronidazole-induced cerebellar syndrome also present with concurrent peripheral neuropathy (e.g., ${ }^{19-21}$ ) and, occasionally, with encephalopathy (e.g., $\left.{ }^{10}\right)$. Therefore, metronidazole-induced neurotoxicity likely represents a spectrum of neurological involvement rather than distinct clinical syndromes.

\section{Clinical Syndromes: 2. Encephalopathy}

Metronidazole-induced encephalopathy can range from confusion (e.g., $\left.{ }^{31}\right)$ to decreased level of consciousness and even coma (e.g., ${ }^{32,33}$ ). (Some reports in the literature, however, use the term encephalopathy to describe any central nervous system toxicity induced by metronidazole even when there are no specific changes in mental status. For consistency, cases labeled as 'encephalopathy' in the literature were included in this group even if by clinical description they appear to have an isolated cerebellar syndrome). Correspondingly, patients with metronidazole-induced encephalopathy appear to have more widespread involvement of the brain on MR imaging, in comparison to the aforementioned cerebellar syndrome. Thus, in addition to symmetrical signal abnormalities within the dentate nuclei, patients with metronidazole-induced encephalopathy can show T2 weighted changes in the subcortical white matter, basal ganglia, corpus callosum (splenium portion in particular) and brainstem ${ }^{31,34,35}$. Generally, clinical and radiological features of encephalopathy are fully reversible upon discontinuation of metronidazole within days (see Table $3 ; 3^{31-45}$ ).

However, three patients presented with severe encephalopathy and did not recover ${ }^{32,33}$. One of these patients had atypical features on the MRI that included signal changes within the centrum semiovale and middle cerebellar peduncles ${ }^{32}$ and presented to medical care after two weeks of ongoing symptoms including dysarthria, somnolence and eventually coma. She had received off-label dosing of intravenous metronidazole as an outpatient (1.5g IV once daily) and presumably high peak serum doses may have contributed to the severity of her presentation and poor prognosis. Another two patients described by Kim et $\mathrm{al}^{33}$ included a patient that remained in a persistent vegetative state at six months despite only receiving a six-day course of metronidazole and another patient who improved clinically but did not fully recover even at a ten month follow-up. The daily and/or cumulative dose of metronidazole is not known for these cases.

Individual variability of patients to both cumulative dose and duration of treatment is also evident in this subgroup of patients (see Table 3). Although most descriptions of metronidazoleinduced encephalopathy include prolonged (two to six months) exposure of 1.5 to $2 \mathrm{~g}$ daily, some patients develop symptoms in less than one week (e.g., ${ }^{33,36,43}$ ). As with the cerebellar syndrome, the reason for this variability is uncertain.

\section{Clinical Syndromes: 3. Seizures}

Metronidazole may produce a variety of seizure semiology including (summarized in Table $4 ;^{45-50}$ ) myoclonus evolving into generalized seizures ${ }^{46}$, generalized tonic clonic seizures ${ }^{47,50}$ and seizures associated with obtundation and encephalopathy ${ }^{45,48}$.

The electroencephalography (EEG) in this group of patients is typically normal (e.g., ${ }^{47}$ ) or may reveal an encephalopathic picture with diffuse slowing but no focal abnormalities (e.g. ${ }^{45,46}$ ). Cumulative doses of metronidazole ranged from $20.7 \mathrm{~g}^{48}$ to $165 \mathrm{~g}^{50}$ on relatively short course of the antimicrobial. Wienbren et $\mathrm{al}^{45}$ describe a patient with seizures starting five days after metronidazole was discontinued and persisting in the first 24 hours despite a phenytoin load.

Some of the reported cases used high daily doses of metronidazole (up to $10.4 \mathrm{~g}$ daily) when it was still being utilized as a radiation sensitizer ${ }^{47}$. Therefore, high peak doses of metronidazole may potentially decrease seizure threshold. However, metronidazole levels within the cerebrospinal fluid do not directly correlate with likelihood of seizures ${ }^{47}$. As most of the studies reporting metronidazole-induced seizures are older, there is a lack of radiological correlation in this subgroup of patients other than a normal CT head in some of the cases ${ }^{45,47}$.

In patients with metronidazole induced seizures, there may be overlap with other metronidazole-induced clinical syndromes as was the case in our patient ${ }^{9}$ with concurrent cerebellar syndrome, worsening peripheral neuropathy and seizures who showed characteristic isolated dentate nuclei hyperintensities on MRI. Importantly, there are no reported cases of ongoing seizures after metronidazole discontinuation. 
Table 3: Summary of case reports of metronidazole-induced encephalopathy. Cases described in the literature as cerebellar syndrome but labeled as encephalopathy are indicted by asterisks (*)

\begin{tabular}{|c|c|c|c|c|c|c|}
\hline Reference & $n$ & Age, Sex & Cumalative Dose (8) & Duration (d) & Rescolutian & Imaxzing \\
\hline Arik et al., 2001 (36) & 1 & $58, F$ & nas & $2 d$ & Prompt resolutice of symplans & CT: nontal. MRI: atrophy abd ischemic clanges \\
\hline Bontenberg of al _, 2011 (34) * & 1 & $55, \mathrm{M}$ & $\sim 1095_{g}$ & $\sim 2 y r s$ & $\begin{array}{l}\text { Cerebellar syndrome and peripheral } \\
\text { neuropathy } \\
\text { Complete resolution at } 5 \text { days post de } \\
\text { of metronidazole }\end{array}$ & $\begin{array}{l}\text { CT: nonmal. MRI: signal changes within the demate, dorsal } \\
\text { pons, inferior olivary nuclel and splenium of the corpus } \\
\text { callosum. fu MRI at } 20 \text { dagx complete resolution of signal } \\
\text { changes }\end{array}$ \\
\hline Caxals et al., $2010(37)$ & 1 & $51, \mathrm{M}$ & $96 \mathrm{~g}$ & $64 d$ & $\begin{array}{l}\text { Resalution of symptotiss I week after } \\
\text { d/c of metronidazole }\end{array}$ & $\begin{array}{l}\text { MRI: T2 hyperintensities involving dentate nuclei, superior } \\
\text { and inferior cercbellar peduncles, central tegmental tract and } \\
\text { inferior olives. fiu MRI at } 5 \text { weeks: complese resolution of } \\
\text { signal changes }\end{array}$ \\
\hline Cheong et al..,2011 (31) & 1 & $57, \mathrm{M}$ & $30 \mathrm{~g}$ & $-36 \mathrm{~d}$ & $\begin{array}{l}\text { Confusion and cerebellar syndrome } \\
\text { Encephalopsthy resolved within } 2 \text { days } \\
\text { of dk of metronidasole }\end{array}$ & $\begin{array}{l}\text { CT: increased density within the corpus callasum } \\
\text { MRI: T2/FL AIR within the dentate nuclei and splenium of } \\
\text { the corpus calloesum: DWI - vasogenic edema within sorpeus } \\
\text { callosum. Du MRI at } 5 \text { weeks: complete resolution }\end{array}$ \\
\hline Desai et al.., 2011 (38) & 1 & $74, \mathrm{M}$ & $n / \mathrm{n}$ & $-190 \mathrm{~d}$ & $\begin{array}{l}\text { Encephalopsthy, cercbellar syndrome } \\
\text { and larpe fiber peripheral newroguthy } \\
\text { Resolution of symplouss al } 6 \text { weeks } \\
\text { escege for residual parasthesine }\end{array}$ & $\begin{array}{l}\text { MRI: restricted diffusice within the splenium of the corpus } \\
\text { callesum with subsle prolcengation of } \mathrm{T} 2 \\
\text { fu MRI a } 5 \text { monsths resolutice of resitricted diffusion with } \\
\text { residual prolongation of } \mathrm{T} 2\end{array}$ \\
\hline Groothoff et al., 2010 (32) & 1 & $38, F$ & $132 . S_{E}$ & $73 d$ & $\begin{array}{l}\text { Encephalopeshyldecreased LOC, } \\
\text { seizures. No dfinical improvement at } 8 \\
\text { weeks - witldrawal of care }\end{array}$ & $\begin{array}{l}\text { CT: widened ventricles } \\
\text { MRI: signal changes within centrum semiovale and } \\
\text { cerebellar peduncles }\end{array}$ \\
\hline \multirow[t]{2}{*}{ Kim et all., 2004 (33) } & 2 & $31, \mathrm{M}$ & $n / a$ & $7 d$ & 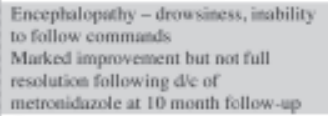 & 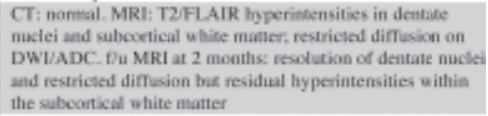 \\
\hline & & $46, M$ & $n / a$ & $\infty$ & $\begin{array}{l}\text { Comatose } \\
\text { Remained in persistent vegetixive state } \\
\text { at six month follow-up }\end{array}$ & $\begin{array}{l}\text { MRI: T2/FL.AIR hyperintensities within subcortical white } \\
\text { maser and deatate muclei; restricsed diffusion within the } \\
\text { subcortical white matser }\end{array}$ \\
\hline \multirow[t]{7}{*}{ Kim et al., $2007(40)^{*}$} & $T$ & $49, M$ & $135 \mathrm{~g}$ & $\begin{array}{l}90 \mathrm{~d} \\
\text { cesset at } 52 \mathrm{~d}\end{array}$ & $\begin{array}{l}\text { Cerebellar syodtrome and Tperipteral } \\
\text { neuropathy } \\
\text { Clinical improvement at } 10 \text { days }\end{array}$ & $\begin{array}{l}\text { MRI: T2/FL.AIR hyperintensities within the dencate, pons } \\
\text { (vestibular, abdacens, superior olivary nucleus) and midtorain } \\
\text { (tegmentum, red nucleus) }\end{array}$ \\
\hline & & $70, \mathrm{M}$ & $57 g$ & $\begin{array}{l}\text { 38d } \\
\text { cesect at } 22 \mathrm{~d}\end{array}$ & $\begin{array}{l}\text { Cerebellar syndrome and } 7 \text { peripberal } \\
\text { neuropathy } \\
\text { Clinical improvement at } 7 \text { days }\end{array}$ & $\begin{array}{l}\text { MRI: T2/FLAIR hyperintensities within the dencate, pons } \\
\text { (vestibular and saperior olivary mucleil, midbrain (tectum, } \\
\text { tegmentum, red nukleus) and corpus callosum }\end{array}$ \\
\hline & & $64, M$ & 37.58 & $\begin{array}{c}25 d \\
\text { coset at 17d }\end{array}$ & $\begin{array}{l}\text { Cerebellar syndrome and Joptic } \\
\text { neuropathy } \\
\text { Clinical improvement at } 7 \text { days }\end{array}$ & $\begin{array}{l}\text { MRI: T2/FL.AIR hyperintensities within the dentate, medulla } \\
\text { (dorsal, inferior olivary nueleus), pons (vestibular and } \\
\text { inferior olivary nueleus), midbrain (fectum and tegmentum). } \\
\text { corpus callosum and subsortical uhite makter } \\
\text { fo MRI af } 17 \text { days: complete nesolution }\end{array}$ \\
\hline & & $54, M$ & 49.5 & $\begin{array}{l}33 \mathrm{~d} \\
\text { ceset as 15d }\end{array}$ & $\begin{array}{l}\text { Encephalopochy - confusion,dysarthria } \\
\text { Clinical improvement at } 5 \text { days }\end{array}$ & $\begin{array}{l}\text { MRI: T2/FL LAIR hyperintensities within the dentate, medulla } \\
\text { (dorsal), pons (vestibular, abducens, inferior olivary nuclei), } \\
\text { midbrain (tegmentum and red nucleus) and corpers callosum }\end{array}$ \\
\hline & & $71, \mathrm{M}$ & $66 \mathrm{~g}$ & $\begin{array}{c}44 d \\
\text { ceset at } 37 d\end{array}$ & $\begin{array}{l}\text { Cerebellar syndrome } \\
\text { Clinical improvement at } 4 \text { days }\end{array}$ & $\begin{array}{l}\text { MRI: T2/FL AIR hy perietensities within the denkate, medulla } \\
\text { (dorsal), pons (vestitelar, abdukens, inferior olivary nuclei), } \\
\text { midbrain (tecium) }\end{array}$ \\
\hline & & $55, \mathrm{M}$ & $21 \mathrm{~g}$ & $\begin{array}{c}14 d \\
\text { censel in IId }\end{array}$ & $\begin{array}{l}\text { Cerebellar syndrome, peripheral } \\
\text { neuropathy } \\
\text { Cinical improvement at } 7 \text { days }\end{array}$ & $\begin{array}{l}\text { MRI: T2/FL.AIR hyperietensities within the dentate, medulla } \\
\text { (dorsal), pons (vestibelar, abducens, inferior olivary nuclei), } \\
\text { midbrain (tectum) and coppus callosum. Fu MRI at } 15 \text { dags: } \\
\text { residual signal changes within corpus callowant }\end{array}$ \\
\hline & & $61, F$ & $40.5 \mathrm{~g}$ & $\begin{array}{l}27 d \\
\text { cescet is } 24 d\end{array}$ & $\begin{array}{l}\text { Cerebellar sysaltome } \\
\text { Clinical improvemeat at } 7 \text { days }\end{array}$ & $\begin{array}{l}\text { MRI: T2/FL.AIR hyperietensities within the denate and } \\
\text { midbrain (tectum) }\end{array}$ \\
\hline Kim et all., 2011 (41) & & $71, \mathrm{M}$ & nía & $14 \mathrm{dV}, 17 \mathrm{~d}$ po & $\begin{array}{l}\text { Encephalopuchy - droosiness, } \\
\text { cerebellar syndrome } \\
\text { Complete resclution at } 3 \text { month }\end{array}$ & 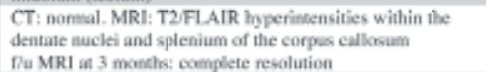 \\
\hline \multirow[t]{8}{*}{ Lee es al ., 2009 (42) } & 8 & GH, M & $\mathrm{RBg}_{\mathrm{g}}$ & $44 d$ & $\begin{array}{l}\text { Cerebellar syadtome, peripheral } \\
\text { neuroparty. Marked improveneat at is } \\
\text { day follow-up }\end{array}$ & $\begin{array}{l}\text { MRL: T2/FL.AIR hyperiatensities within the denate and } \\
\text { inferior colliculus; low ADC map } \\
\text { fu MRI at } 4 \text { days: complete resolution }\end{array}$ \\
\hline & & $\omega, \mathrm{M}$ & $120 \mathrm{~g}$ & cod & $\begin{array}{l}\text { Cerebellar syndrome } \\
\text { Marked improvement as } 15 \text { day follow. } \\
\text { up }\end{array}$ & $\begin{array}{l}\text { MRL: T2/FL.AIR hyperintensities within the denate, inferior } \\
\text { colliculus and medulla } \\
\text { ffu MRI at } 15 \text { days: complete resolution }\end{array}$ \\
\hline & & $64, F$ & $100 \mathrm{~g}$ & $50 \mathrm{~d}$ & $\begin{array}{l}\text { Gait disturbance - ?atasia } \\
\text { Marked improvement as } 15 \text { day follow: } \\
\text { up }\end{array}$ & $\begin{array}{l}\text { MRI: T2/FL_AIR hyperintensities within the dentate, inferior } \\
\text { colliculus and pons. fiu MRI at is days complese resolution }\end{array}$ \\
\hline & & $43, \mathrm{M}$ & $45_{g}$ & $30 d$ & $\begin{array}{l}\text { Cerebellar syndrome. Marked } \\
\text { improvement at } 15 \text { day follow-up }\end{array}$ & $\begin{array}{l}\text { MRI: T2/FL.AIR hyperintensities within the dentate, inferior } \\
\text { colliculus and pons }\end{array}$ \\
\hline & & $78, F$ & $80 \mathrm{~g}$ & $40 \mathrm{~d}$ & $\begin{array}{l}\text { Gait disturtance - ?atasia } \\
\text { Marked improvement at } 8 \text { day follow- } \\
\text { up }\end{array}$ & $\begin{array}{l}\text { MRI: T2/FLAIR hyperintensities within the dentate, inferior } \\
\text { colliculus, corpus callosum and cerebral whine matter }\end{array}$ \\
\hline & & $76, F$ & $100 \mathrm{~g}$ & Sod & $\begin{array}{l}\text { Dysarthria - Foerebellar } \\
\text { Improvement at } 13 \text { day follow-up }\end{array}$ & 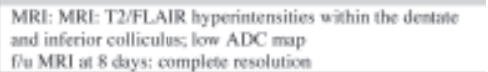 \\
\hline & & $61, \mathrm{M}$ & $120 \mathrm{~g}$ & gad & $\begin{array}{l}\text { Cerebellar syndrome and peripheral } \\
\text { neuropathy } \\
\text { Improvement af } 18 \text { day follow-up }\end{array}$ & $\begin{array}{l}\text { MRI: T2/FLAIR hyperimtensities within the denate and } \\
\text { corpus callosum; low ADC map. fou MRI af } 6 \text { days: residual } \\
\text { signal changes within the corvus callosum }\end{array}$ \\
\hline & & $47, \mathrm{M}$ & $100 \mathrm{~g}$ & sod & $\begin{array}{l}\text { Dysarthria - 3cerebellar } \\
\text { Improvement at } 15 \text { day follow-up }\end{array}$ & MRI: T2/FL.AIR hyperintensities within the dernate nucleus \\
\hline Hammami el all., 2007 (39) & 1 & $51, \mathrm{M}$ & $31.5 \mathrm{~g}$ & $21 \mathrm{~d}$ & $\begin{array}{l}\text { Cenebellar, vestibular, posterior column } \\
\text { and paramidal involvetsent }\end{array}$ & $\begin{array}{l}\text { MRI: T2/FLAIR hyperietensities within the dentate nuclei, } \\
\text { splestium of the corpus callosum and diffuse cluatges within } \\
\text { the brainstem }\end{array}$ \\
\hline Omotose and Opadijo, $1997(43)$ & 1 & $48, \mathrm{M}$ & n/a & $3 d$ & $n / a$ & $n / 4$ \\
\hline Park et al., $2011(44)$ " & 1 & $67, \mathrm{M}$ & $\begin{array}{l}75 \mathrm{~g} \text { at onset } \\
\text { (127.5g tocal) }\end{array}$ & $250 d$ & 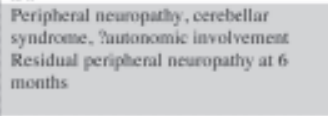 & $\begin{array}{l}\text { MRI: T2/FL.AIR hyperintensities within subcortical white } \\
\text { master and dentate nuclei; restricted diffusion within the } \\
\text { subcortical white matter } \\
\text { flu MRI at } 1 \text { week: improvement in signal changes with wo } \\
\text { restricuted diffusion }\end{array}$ \\
\hline Seok es al__ 2003 (35) & 1 & $74, F$ & $90 \mathrm{~g}$ & 900 & $\begin{array}{l}\text { MMSE 19/30, cerebellar syndrome, } \\
\text { peripheral neuropothy and ooguhed } \\
\text { rigidity: paticat had co-existent vitamin } \\
\text { Bi2 deficiency } \\
\text { Remained on metronidaxole for another } \\
\text { three month after symptom enset } \\
\text { Sympecens resolved within } 4 \text { months }\end{array}$ & $\begin{array}{l}\text { MRI: T2/FL.AIR hyperintensities within the suboontical whits } \\
\text { manter, anterior commissure, basal ganglia, dentante nuclei, } \\
\text { spleatiom of the corpus callosum, inferior olivary nuclei and } \\
\text { midbrain } \\
\text { f/u MRI at } 4 \text { monchs: resolutioe of signal changes except } \\
\text { within inferior olivary nuclei now demoestrating hypertrophy }\end{array}$ \\
\hline Wienbren et al., 1985 (45) & 1 & 43, F & $\begin{array}{l}18.5 \mathrm{~g} \mathrm{IV}, 10 \mathrm{~g}(28.5 \mathrm{~g} \\
\text { tocal })\end{array}$ & $12 \mathrm{~d}, 10 \mathrm{~d}$ & $\begin{array}{l}\text { Encephaloposty and seizures } \\
\text { Clinical resolution within } 48 \text { hours }\end{array}$ & CT: nonmal \\
\hline
\end{tabular}


Table 4: Summary of case reports of metronidazole-induced seizures

\begin{tabular}{|c|c|c|c|c|c|c|}
\hline Reference & $\mathrm{n}$ & Age, Sex & Cumulative Dose (R) & Duration (d) & Resolution & Imaging \\
\hline Beloosesky et al.., $2000(46)$ & 1 & $87, F$ & $18 \mathrm{~g}, 10.5 \mathrm{~g}, 4.5 \mathrm{~g}$ & $12 d, 7 d, 3 d$ & $\begin{array}{l}\text { No recurrent seizures after dic MTZ } \\
\text { EEG } * 1 \text { : nomal.EEG } \& 2 \text { : diffuse slowing (delta/theta) }\end{array}$ & n'a \\
\hline \multirow[t]{3}{*}{ Frytak et al., 1978 (47) } & \multirow[t]{3}{*}{3} & $52, \mathrm{~F}$ & $52 \mathrm{~g}$ & $10 \mathrm{~d}$ & $\begin{array}{l}\text { 'motoc' seizure. EEG: no focal or epileptogenic activity. } \\
\text { No recurrent seizure after dic MTZ }\end{array}$ & CT (enhanced): unremarkable \\
\hline & & 77, F & $26 \mathrm{~g}$ & $10 \mathrm{~d}$ & 'motor' seizure. EEG: nomal. No recurrent seizures & CT: nomal \\
\hline & & $75, \mathrm{~F}$ & $42 \mathrm{~g}$ & $7 d$ & 'motor' seizure. EEG: nomal. No recurrent seizures & CT: normal \\
\hline George et al.., 1982 (48) & 1 & $61, \mathrm{M}$ & $20.7 \mathrm{~g}$ IV & $18 d$ & Grand mal seizures with obtundation and death & n/a \\
\hline Halloran et al., $1982(49)$ & 1 & $56, \mathrm{M}$ & $33.6 \mathrm{~g}$ & $16 d$ & Resolution & $n / a$ \\
\hline Herreman et al., 1981 (50) & 1 & $20, \mathrm{~F}$ & $165 g$ & $68 \mathrm{~d}$ & $\begin{array}{l}\text { GTC seizures } x 4 \text { and neuropathy symptoms } \\
\text { No recurrent seizures after dic MTZ }\end{array}$ & n'a \\
\hline Wienbren et al., 1985 (45) & 1 & 43, F & $\begin{array}{l}18.5 \mathrm{~g} \mathrm{IV}, 10 \mathrm{~g}(28.5 \mathrm{~g} \\
\text { tocal })\end{array}$ & $12 \mathrm{~d}, 10 \mathrm{~d}$ & $\begin{array}{l}\text { GTC seizures after MTZ discontinued; several within first } 24 \text { hrs despite } \\
\text { tx with PHT. EEG: encephalopathy }\end{array}$ & CT: normal \\
\hline
\end{tabular}

\section{Clinical Syndromes: 4. Optic Neuropathy}

Optic neuropathy may be a rare complication of metronidazole treatment (summarized in Table 5; 15,51-53). The link in the literature is not as clearly established. Patients have been described to develop subacute to chronic changes in visual acuity after prolonged treatment regimens of one to two years ${ }^{15,51,52}$. Marked improvement within days to weeks occurs immediately after discontinuation of metronidazole but full recovery was reported to take as long as a year (e.g. $\left.{ }^{51}\right)$. Putnam et $\mathrm{al}^{53}$ reported a series of seven patients collectively by reviewing the National Registry of Drug-Induced Ocular Side Effects (Casey Eye Institute, Oregon Health Sciences University, Portland, Oregon). The reported symptoms consisted of abnormal color vision, scotomas and reduced visual acuity. One of the patients developed symptoms after only seven days of metronidazole therapy and in two of the reported patients the deficits were irreversible ${ }^{53}$.

While at least one patient had a normal MRI ${ }^{52}$ another had isolated splenium of the corpus callosum hyperintensities ${ }^{15}$. Cecil et $\mathrm{al}^{51}$ describe a patient with a thickened splenium of the corpus callosum and marked signal changes within the basal ganglia and midbrain. Magnetic resonance spectroscopy (MRS) revealed elevated lactate peaks within the involved structures. Interestingly, there are no case reports of metronidazole-induced signal changes within the optic nerve.

\section{Clinical Syndromes: 5. Autonomic Neuropathy}

There is only one convincing case description of autonomic neuropathy secondary to metronidazole. This patient, a 15-yearold girl, developed severe painful peripheral sensorimotor neuropathy with absent sympathetic skin responses following a short course (reported as days of treatment) of metronidazole ${ }^{54}$. Extensive investigations were completed to rule out an alternative diagnosis or contributing cause. These included lumbar puncture, serum protein electrophoresis, rheumatoid factor, vitamin $\mathrm{B}_{12}$, porphyrins, erythrocyte sedimentation rate (ESR), Lyme titer, antinuclear antibodies and lead, mercury and arsenic plasma levels. Symptoms were not immediately reversible upon discontinuation of metronidazole and multiple interim medications were required for the management of disabling neuropathic pain. Electrophysiological parameters and patient symptoms normalized at six months post cessation of metronidazole. Wienbren et $\mathrm{al}^{45}$ suspected autonomic involvement in their patient who had urinary retention for 48 hours as well as concurrent seizures.

\section{Clinical Syndromes: 4c. Peripheral Sensory or Sensorimotor Neuropathy}

There are numerous reports of metronidazole-induced peripheral neuropathy in the literature and it remains the bestrecognized neurologic side effect of metronidazole (selected cases are summarized in Table 5; ${ }^{10,19,48,55-62}$ ). In fact, many of the patients reported as having a cerebellar syndrome or encephalopathy, had co-existing neuropathic symptoms and/or findings (see Table 2 and 3). The neuropathy can be painful, severe and cause significant permanent disability (e.g. $\left.{ }^{48}\right)$.

Although patients with coexisting central nervous system involvement have the typical radiological findings, patients with isolated peripheral sensory neuropathy do not appear to as demonstrated by one case report that included a normal MRI brain and cervical spine ${ }^{62}$.

Metronidazole-induced neuropathy is characterized by a slowly progressive symmetric distal sensory neuropathy with primary small fiber involvement. Large fibers are affected subclinically in most cases. Routine electrodiagnostic studies may therefore be normal and quantitative sensory testing (QST), quantitative sudomotor autonomic reflex testing (QSART) and skin biopsy are more sensitive in this clinical setting. (e.g. ${ }^{62}$ ). Gupta et $\mathrm{al}^{19}$ described the only patient with a severe distal sensory neuropathy and an associated proximal motor neuropathy without resolution post discontinuation of metronidazole.

The proposed pathophysiology in metronidazole induced peripheral sensory neuropathy is axonal degeneration ${ }^{60,63}$ and this may account for prolonged symptoms even after drug cessation. Human sural nerve biopsy studies have confirmed axonal degeneration in both myelinated and unmyelinated fibres ${ }^{60}$. Wallerian degeneration was confirmed in about $56 \%$ of fibers ${ }^{63}$ while demyelination was relatively rare involving only $4 \%$. The latter was thought to be a consequence of axonal pathology.

\section{MR Imaging findings of Metronidazole Toxicity}

The most common radiological abnormality induced by metronidazole consists of bilateral and symmetrical $\mathrm{T} 2$ and FLAIR hyperintensities within the dentate nuclei of the cerebellum on MR imaging (see Figure 1). There is no associated mass effect or enhancement but, occasionally, there is a subtle T1 
Table 5: Summary of case reports of optic, autonomic and selected cases of peripheral neuropathy secondary to metronidazole treatment

\begin{tabular}{|c|c|c|c|c|c|c|}
\hline Reference & $n$ & Age, Sex & Cumulative Dose (B) & Duration (d) & Resalution & Imaging \\
\hline \multicolumn{7}{|l|}{ Optic Neuropathy } \\
\hline Cecil et al.. 2002 (51) & 1 & $17, \mathrm{M}$ & $n / a$ & $\mathrm{~B} / \mathrm{a}$ & $\begin{array}{l}\text { Slight improvement in visual acuity at } 1 \text { month, } \\
\text { marked improvement at } 3 \text { months and full resolution } \\
\text { at } 1 \text { year. (ocher symptoms; cerebella syndrome and } \\
\text { peripheral neuropathy) }\end{array}$ & $\begin{array}{l}\text { MRI: T2/FLAIR byperintensities withis the corpus } \\
\text { callosum (associaned with thickening), midbrain and } \\
\text { basal ganglia. MRS: elevated lactate peaks (basal } \\
\text { ganglia and splenium of the corpus callosum) }\end{array}$ \\
\hline De Bleecker et al., 2005 (15) & 1 & $20, \mathrm{M}$ & $1095 \mathrm{~g}$ & -730d & $\begin{array}{l}\text { Improvement within } 2 \text { weeks of d/c } \\
\text { Resolution within } 14 \text { monshs }\end{array}$ & $\begin{array}{l}\text { MRI: T2/FL.AIR signal hyperintensities within the } \\
\text { splenium of the corpus callosum }\end{array}$ \\
\hline McGrath et al., 2007 (52) & 1 & $67, \mathrm{~F}$ & $\sim 360 \mathrm{~g}$ & $\sim 300 \mathrm{~d}$ & $\begin{array}{l}\text { Improvement within } 4 \mathrm{~d} \text { of } \mathrm{d} / \mathrm{c} \\
\text { Resolution of optic neuropathy }\end{array}$ & MRI: normal \\
\hline Putnam et al.., I99I (53) & 7 & $\begin{array}{r}26-53 \mathrm{yo} ; \\
4 \mathrm{~W}, 5 \mathrm{M} \\
\end{array}$ & n'a & 7 to $365 \mathrm{~d}$ & $\begin{array}{l}\text { Two out of seven patients had residual deficits in } \\
\text { vision; peripheral neuropathy in two }\end{array}$ & $n / a$ \\
\hline \multicolumn{7}{|l|}{ Autonomic Neuropathy } \\
\hline Hobson-Webb et al., 2006 (54) & 1 & $15, \mathrm{~F}$ & $n / a$ & Short course & $\begin{array}{l}\text { Dramadic improvement } 3 \text { mo later } \\
\text { Complete resolution by } 6 \text { mo }\end{array}$ & MRIMRA: normal \\
\hline Wienbres et al., 1985 (45) & 1 & $43, \mathrm{~F}$ & $\begin{array}{l}18.5 \mathrm{~g} \mathrm{IV}, 10 \mathrm{~g}(28.5 \mathrm{~g} \\
\text { tocal })\end{array}$ & $12 d, 10 d$ & $\begin{array}{l}\text { Urinary retention } \times 48 \text { hours - autonomic } \\
\text { involvement suspected; ?other cause } \\
\text { GTC seizures after MTZ discontinued }\end{array}$ & CT: bormal \\
\hline \multicolumn{7}{|l|}{ Peripheral Nearopathy } \\
\hline Bradley et al., 1977 (55) & 1 & $33, \mathrm{M}$ & $-336 g \mathrm{~g}$ & $9 \mathrm{mo}$ & $\begin{array}{l}\text { Sensory symptoms started at } 8 \text { weeks } \\
\text { EMG - distal, primarily sensory peripheral } \\
\text { neuropathy }\end{array}$ & n'a \\
\hline \multirow[t]{2}{*}{ Coson and Pallis, $1976(56)$} & 2 & $60 . \mathrm{F}$ & $30.6 \mathrm{~g}$ & $50 \mathrm{~d}$ & Improvement of symptoms at 1 monh & n/a \\
\hline & & $40, \mathrm{M}$ & $114 \mathrm{~g}$ & $63 \mathrm{~d}$ & No improvement at 1 moesh follow-Up & n'a \\
\hline \multirow[t]{2}{*}{ George et al.. 1982 (48) } & 2 & 43. M & $27.5 \mathrm{~g}$ iv $+101.3 \mathrm{~g}$ po & $58 \mathrm{~d}$ & - & n'a \\
\hline & & $48, M$ & $4.1 \mathrm{~g}$ iv $+15.8 \mathrm{~g}$ po & $9 \mathrm{~d}$ & Severe sensory neuroparhy & n'a \\
\hline Gupxa et al.. 2000 (57) & 1 & $25, \mathrm{M}$ & $18 \mathrm{~g}$ & ISd & - & n/a \\
\hline Gupea et al., 2003 (13) & 1 & $50, \mathrm{M}$ & $200 \mathrm{~g}$ & $84 d$ & Other features: cerebellar syndrome, encephalopathy & CT: bypodensities within the cerebellum \\
\hline Kusumi et al., 1980 (10) & 1 & $45, \mathrm{~F}$ & $84 \mathrm{~g}$ & $28 \mathrm{~d}$ & - & n/a \\
\hline Ramsay, 1968 (58) & 1 & $43, M$ & $135 g$ & $113 \mathrm{~d}$ & - & n'a \\
\hline Sarma and Kamath, 2005 (59) & 1 & $45, \mathrm{~F}$ & $3.6 \mathrm{~g}$ & $3 \mathrm{~d}$ & Improvement of symptoms upon discontinuation & n/a \\
\hline Takeuchi et al., 1988 (60) & 1 & $67, \mathrm{M}$ & $101.25 \mathrm{~g}$ & - & - & n/a \\
\hline Tan et al., $2011(61)$ & 1 & $53, \mathrm{M}$ & 1462 & $88 \mathrm{~d}$ & Length-dependent painful neuropthy & n'a \\
\hline \multirow{4}{*}{ Zivkovic et al., 2001 (62) } & 4 & $52, \mathrm{M}$ & $180 \mathrm{~g}$ & $90 \mathrm{~d}$ & Symptom onset at 10 weeks & n/a \\
\hline & & $34, \mathrm{~F}$ & $n / \mathbf{a}$ & $\begin{array}{c}120 \mathrm{~d} \\
\text { (intermittent) }\end{array}$ & Symptoms resolved post discontinuation & MRI brain and $\mathrm{C}$-spine: unremarkable \\
\hline & & $55, \mathrm{M}$ & $3650 \mathrm{~g}$ & $3650 d$ & - & ña \\
\hline & & $51, \mathrm{~F}$ & (topical) & $270 d$ & - & n/a \\
\hline
\end{tabular}

hypointensity noted $\left(\right.$ e.g.,$\left.^{20}\right)$. This finding of involvement of the cerebellar dentate nuclei, is almost pathognomonic, although a small, less likely differential can be invoked (eg, Wernicke's encephalopathy, Friedreich's ataxia, CADASIL, cerebrotendinous xanthomatosis). Typically, patients with these changes on MR imaging show a cerebellar syndrome, with or without a peripheral neuropathy.

In patients with metronidazole-induced encephalopathy, involvement of the splenium of the corpus callosum is also frequently found either in isolation or in association with dentate nuclei signal abnormalities (e.g., ${ }^{31,34,35}$ ). Other sites of involvement, include midbrain, pons, medulla, subcortical white matter, basal ganglia, anterior commissure and middle cerebellar peduncle $31,34,35$.

Generally, MR signal abnormalities are fully reversible with drug discontinuation and are therefore attributed to axonal swelling (i.e. increased water content) instead of a demyelinating process $^{35}$. Alternatively, Ahmed et $\mathrm{al}^{11}$ proposed that these changes may represent vascular spasm and transient reversible ischemia.

Many case reports of MRI findings describe high diffusion weighted imaging (DWI) signal associated with low apparent diffusion coefficient (ADC) values suggesting cytotoxic edema within the corpus callosum, basal ganglia, brainstem and subcortical white matter ${ }^{35,40}$. Dentate nuclei, however, typically demonstrate high DWI signal associated with high ADC values indicative of vasogenic edema ${ }^{40,42}$. Cecil et $\mathrm{al}^{51}$ reported proton
MRS findings in a patient with metronidazole toxicity demonstrating a high lactate peak.

\section{Animal Studies of Metronidazole Toxicity}

Reports of metronidazole-induced neurotoxicity in cats and dogs include a cerebellar syndrome, seizures, changes in level of consciousness and nystagmus ${ }^{64-67}$. It is not clear whether the doses are comparable to those used in humans. Scharer et $\mathrm{al}^{67}$ demonstrated clear loss of Purkinje cells in dogs exposed to metronidazole - clinical recovery would therefore be unexpected.

Experimental models aimed at studying metronidazole toxicity are not current. Animal studies have clearly shown that ${ }^{14} \mathrm{C}$-metronidazole crosses the blood-brain barrier and accumulates within the brain particularly within the hippocampus, olfactory bulb and cerebellum ${ }^{68}$. Moreover, autoradiographic studies of the hippocampus and cerebellum showed that these structures retain activity for longer periods of time ${ }^{68}$ perhaps accounting for the recognized clinical and radiological toxicity of metronidazole within the cerebellum noted within the human literature.

Administration of high doses of metronidazole to rats (800 $\mathrm{mg} / \mathrm{kg} /$ day over six weeks) has been shown to produce symmetrical lesions within the vestibular and cochlear nuclei as well as cerebellar nuclei ${ }^{69}$. The involved sites were strikingly similar to those found in Wernicke's encephalopathy. However, the doses were approximately 25 -fold higher than the maximum 
Most common

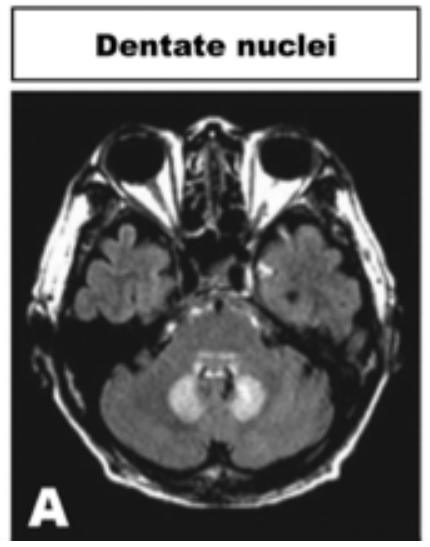

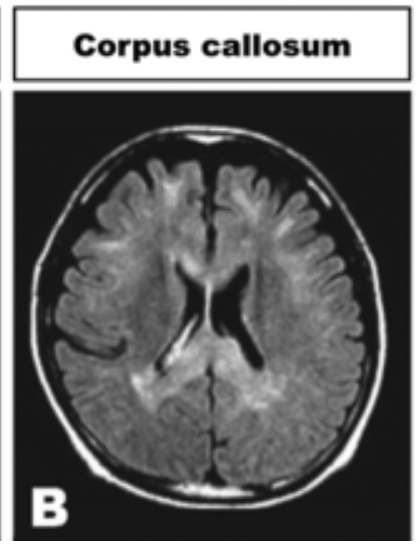

Least common

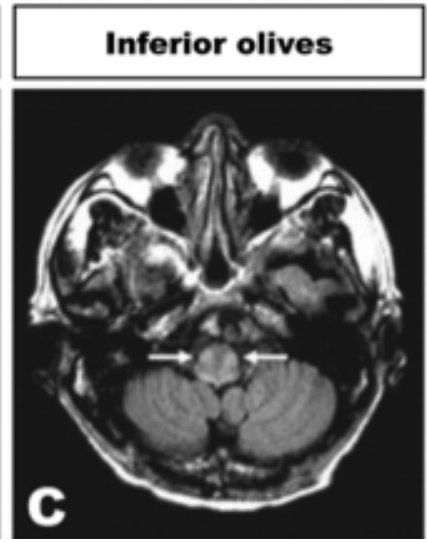

Subcortical WM

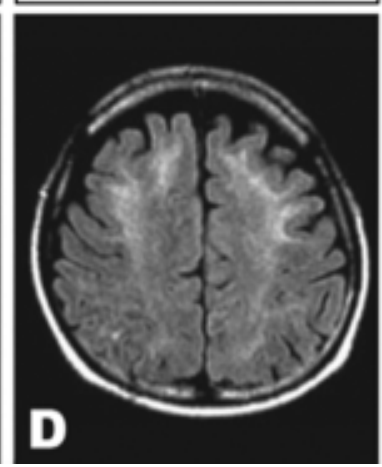

Figure: Summary of metronidazole-induced MRI features from most common (left, A) to least common (right, D). Metronidazole-induced MRI FLAIR hyperintensities are found within the cerebellar dentate nuclei $(A)$, corpus callosum (splenium) $(B)$, inferior olives $(C)$ and subcortical white matter (WD) (D). (Adapted from Kim et al. (40) with permission).

recommended dose in humans. Furthermore, metabolism of metronidazole, at least in mice and rats, has been shown to be different than in humans ${ }^{70}$ and animal studies need to be extrapolated with caution. Administration of metronidazole to rats at doses comparable to humans, did not result in cerebellar or brainstem lesions ${ }^{55}$. Radioactively-labeled metronidazole was found to bind to RNA and thus neurotoxicity may be related to inhibition of protein synthesis by metronidazole or one of its metabolites $^{55}$.

\section{Pathophysiology}

The pathophysiology underlying metronidazole neurotoxicity remains elusive although several possible mechanisms have been proposed. It is not known whether metronidazole itself is neurotoxic or whether the culprit is one of its metabolites.

Metronidazole has been shown to bind to RNA and proposed to inhibit protein synthesis thereby presumably leading to axonal degeneration ${ }^{55}$. Others have postulated that metronidazole leads to free radical formation ${ }^{71}$.

Alston $^{72}$ hypothesized that neurotoxicity may be related to metronidazole's structural similarity to the thiazole precursor of thiamine. Gut flora possessing thiaminase activity may be involved in the conversion of metronidazole to a thiamine antagonist. Whether the neurotoxic side effects could be mitigated by supplemental thiamine administration has never been explored although the similarity in MR changes between Wernicke's encephalopathy and metronidazole induced encephalopathy is intriguing.

Recently, similar neurotoxicity was described in a related 5nitro-imidazole derivative, ornidazole ${ }^{73}$. Symmetric and reversible T2/FLAIR hyperintensities within the dentate nuclei were also found. Interestingly, another related compound tonidazole - did not cause neurotoxicity in a patient who previously developed a metronidazole-induced cerebellar syndrome ${ }^{24}$. However, toxic doses of tonidazole in another patient who was self-medicating, resulted in side effects and radiological findings identical to metronidazole ${ }^{74}$. Thus, neurotoxicity of 5-nitro-imidazole derivatives likely shares the same pathophysiology.

Metronidazole levels are not routinely measured in patients with neurologic complications. While some patients clearly have toxic metronidazole levels (e.g., ${ }^{16,18,21}$ ) others do not (e.g., ${ }^{29}$ ). Although there are no consistent patient-related factors, some have suggested that advanced age as well as renal and hepatic dysfunction may confer a higher risk of developing metronidazole-related side effects.

Alston $^{75}$ studied metronidazole metabolism in the elderly (over 70 years-old) and healthy controls, concluding that in the elderly the smaller volume of distribution, declining renal function and reduced red cell binding of metronidazole results in higher serum levels potentially leading to neurotoxicity. However, similar experiments ${ }^{76}$ found no difference in metabolism of metronidazole in the elderly (studied patients 86 +/- 6 years-old) and recommended no changes to dosing.

Hepatic dysfunction leads to impaired hepatic oxidation and, therefore, reduced metronidazole elimination ${ }^{30}$. Similarly, severe renal failure increases metronidazole's half-life from 9.2 hours to 28 hours $^{77}$. Therefore, prudent use and/or dose adjustment in these clinical scenarios would seem to be warranted.

Kuriyama et $\mathrm{al}^{78}$ conducted a systematic review to ascertain patient and medication-related features associated with metronidazole toxicity. Based on inclusion criteria, 64 patients were included in the analysis. The most common presentation of metronidazole neurotoxicity is a cerebellar syndrome (present in $77 \%$ of patients) followed by encephalopathy (33\%). Although side effects were more commonly associated with chronic 
treatment regimens, $26 \%$ of patients developed symptoms in less than a week. The authors concluded that dose and duration of treatment are ultimately not correlated with central nervous system toxicity.

\section{Discussion ANd Conclusions}

Despite its widespread use in clinical practice, the neurotoxicity of metronidazole continues to be under recognized. In fact, patients are not usually informed about the potential neurologic complications when being started on this antimicrobial. Fortunately, serious side effects continue to be relatively rare and often fully reversible before a diagnosis is made. These side effects may also be less obvious in complicated patients due to polypharmacy or coexisting conditions predisposing them to neuropathy, seizures or even ataxia.

More recently, there has been a surge of case reports on its neurotoxic effects likely attributable to more widespread and chronic use of metronidazole (i.e. more affected patients) as well as routine MRI imaging demonstrating the typical T2 and FLAIR signal changes (i.e. identification of metronidazole as an offending neurotoxic agent).

Recognition of the neurotoxic effects of metronidazole cannot be overemphasized, as prompt discontinuation is associated with a favorable long-term prognosis. Moreover, heightened index of suspicion about neurological syndromes produced by metronidazole may decrease the need for extensive investigations. When metronidazole is suspected to be the cause of neurological symptoms, however, it should remain a diagnosis of exclusion to ensure that no other reversible cause is missed particularly in the absence of characteristic MRI findings.

\section{REFERENCES}

1. Finegold SM. Metronidazole. Ann Intern Med. 1980 Oct;93(4): 585-7.

2. Ralph ED. Clinical pharmacokinetics of metronidazole. Clin Pharmacokinet. 1983 Jan-Feb;8(1):43-62.

3. Ralph ED, Clarke JT, Libke RD, Luthy RP, Kirby WM. Pharmacokinetics of metronidazole as determined by bioassay. Antimicrob Agents Chemother. 1974 Dec;6(6):691-6.

4. Jokipii AM, Myllyla VV, Hokkanen E, Jokipii L. Penetration of the blood brain barrier by metronidazole and tinidazole. J Antimicrob Chemother. 1977 May;3(3):239-45.

5. Phongsamran PV, Kim JW, Cupo Abbott J, Rosenblatt A. Pharmacotherapy for hepatic encephalopathy. Drugs. 2010 Jun 18;70(9):1131-48.

6. Perencevich M, Burakoff R. Use of antibiotics in the treatment of inflammatory bowel disease. Inflamm Bowel Dis. 2006 Jul;12 (7):651-64.

7. Eyre HJ, Ohlsen JD, Frank $J$, et al. Randomized trial of radiotherapy versus radiotherapy plus metronidazole for the treatment metastatic cancer to brain. A Southwest Oncology Group study. J Neurooncol. 1984;2(4):325-30.

8. Aiken R, Leavengood JM, Kim JH, Deck MD, Thaler HT, Posner JB. Metronidazole in the treatment of metastatic brain tumors. Results of a controlled clinical trial. J Neurooncol. 1984;2(2): 105-11.

9. Sarna JR, Brownell AK, Furtado S. Cases: Reversible cerebellar syndrome caused by metronidazole. CMAJ. 2009 Oct 27;181(9): 611-3.

10. Kusumi RK, Plouffe JF, Wyatt RH, Fass RJ. Central nervous system toxicity associated with metronidazole therapy. Ann Intern Med. 1980 Jul;93(1):59-60.

11. Ahmed A, Loes DJ, Bressler EL. Reversible magnetic resonance imaging findings in metronidazole-induced encephalopathy. Neurology. 1995 Mar;45(3 Pt 1):588-9.
12. Alvarez RS, Richardson DA, Bent AE, Ostergard DR. Central nervous system toxicity related to prolonged metronidazole therapy. Am J Obstet Gynecol. 1983 Mar 1;145(5):640-1.

13. Bonkowsky JL, Sondrup C, Benedict SL. Acute reversible cerebellar lesions associated with metronidazole therapy. Neurology. 2007 Jan 16;68(3):180.

14. Chatzkel JA, Vossough A. Metronidazole-induced cerebellar toxicity. Pediatr Radiol. 2010 Aug;40(8):1453.

15. De Bleecker JL, Leroy BP, Meire VI. Reversible visual deficit and Corpus callosum lesions due to metronidazole toxicity. Eur Neurol. 2005;53(2):93-5.

16. Deenadayalu VP, Orinion EJ, Chalasani NP, Yoo HY. Abnormal enhancing lesion of dentate nuclei causing neurologic symptoms induced by metronidazole toxicity. Clin Gastroenterol Hepatol. 2005 Mar;3(3):xxix.

17. Galvez M, Brahm J, Miranda M. Movement disorders as a manifestation of metronidazole-induced encephalopathy in a patient with chronic liver disease. Mov Disord. 2009 Sep 15;24 (12):1864-6.

18. Graves TD, Condon M, Loucaidou M, Perry RJ. Reversible metronidazole-induced cerebellar toxicity in a multiple transplant recipient. J Neurol Sci. 2009 Oct 15;285(1-2):238-40.

19. Gupta AK, Agarwal MP, Avasthi R, Bhadoria DP, Rohatgi N. Metrondazole-induced neurotoxicity. J Assoc Physicians India. 2003 Jun;51:617-8.

20. Heaney CJ, Campeau NG, Lindell EP. MR imaging and diffusionweighted imaging changes in metronidazole (Flagyl)-induced cerebellar toxicity. AJNR Am J Neuroradiol. 2003 Sep;24(8): 1615-7.

21. Horlen CK, Seifert CF, Malouf CS. Toxic metronidazole-induced MRI changes. Ann Pharmacother. 2000 Nov;34(11):1273-5.

22. Ito $\mathrm{H}$, Maruyama $\mathrm{M}$, Ogura $\mathrm{N}$, et al. Reversible cerebellar lesions induced by metronidazole therapy for helicobacter pylori. J Neuroimaging. 2004 Oct;14(4):369-71.

23. Kalia V, Vibhuti, Saggar K. Case report: MRI of the brain in metronidazole toxicity. Indian J Radiol Imaging. 2010 Aug;20 (3):195-7.

24. Lawford R, Sorrell TC. Amebic abscess of the spleen complicated by metronidazole-induced neurotoxicity: case report. Clin Infect Dis. 1994 Aug;19(2):346-8.

25. Moosa AN, Perkins D. Neurological picture. MRI of metronidazole induced cerebellar ataxia. J Neurol Neurosurg Psychiatry. 2010 Jul;81(7):754-5

26. Patel K, Green-Hopkins I, Lu S, Tunkel AR. Cerebellar ataxia following prolonged use of metronidazole: case report and literature review. Int J Infect Dis. 2008 Nov;12(6):e111-4.

27. Takase K, Santa Y, Ohta S, Yoshimura T. [MRI and SPECT findings in a case of metronidazole-induced reversible acute cerebellar ataxia]. Rinsho Shinkeigaku. 2005 May;45(5):386-9.

28. Toumi S, Hammouda M, Essid A, Medimagh L, Slamia LB, Laouani-Kechrid C. [Metronidazole-induced reversible cerebellar lesions and peripheral neuropathy]. Med Mal Infect. 2009 Dec;39(12):906-8.

29. Woodruff BK, Wijdicks EF, Marshall WF. Reversible metronidazole-induced lesions of the cerebellar dentate nuclei. N Engl J Med. 2002 Jan 3;346(1):68-9.

30. Loft S, Sonne J, Dossing M, Andreasen PB. Metronidazole pharmacokinetics in patients with hepatic encephalopathy. Scand J Gastroenterol. 1987 Jan;22(1):117-23.

31. Cheong HC, Jeong TG, Cho YB, et al. Metronidazole-induced encephalopathy in a patient with liver cirrhosis. Korean $\mathrm{J}$ Hepatol. 2011 Jun;17(2):157-60.

32. Groothoff MV, Hofmeijer J, Sikma MA, Meulenbelt J. Irreversible encephalopathy after treatment with high-dose intravenous metronidazole. Clin Ther. 2010 Jan;32(1):60-4.

33. Kim DW, Park JM, Yoon BW, Baek MJ, Kim JE, Kim S. Metronidazole-induced encephalopathy. J Neurol Sci. 2004 Sep $15 ; 224(1-2): 107-11$.

34. Bottenberg MM, Hegge KA, Eastman DK, Kumar R. Metronidazole-induced encephalopathy: a case report and review of the literature. J Clin Pharmacol. 2011 Jan;51(1):112-6. 
35. Seok JI, Yi H, Song YM, Lee WY. Metronidazole-induced encephalopathy and inferior olivary hypertrophy: lesion analysis with diffusion-weighted imaging and apparent diffusion coefficient maps. Arch Neurol. 2003 Dec;60(12):1796-800.

36. Arik N, Cengiz N, Bilge A. Metronidazole-induced encephalopathy in a uremic patient: a case report. Nephron. 2001 Sep;89(1): $108-9$.

37. Cazals X, Omoumi P, Agnard P, et al. [Reversible metronidazoleinduced encephalopathy and hypertrophic olivary degeneration]. J Radiol. 2010 Mar;91(3 Pt 1):304-6.

38. Desai JA, Dobson J, Melanson M, Pari G, Jin AY. Metronidazoleinduced encephalopathy: case report and review of MRI findings. Can J Neurol Sci. 2011 May;38(3):512-3.

39. Hammami N, Drissi C, Sebai R, et al. Reversible metronidazoleinduced encephalopathy. J Neuroradiol. 2007 May;34(2):133-6.

40. Kim E, Na DG, Kim EY, Kim JH, Son KR, Chang KH. MR imaging of metronidazole-induced encephalopathy: lesion distribution and diffusion-weighted imaging findings. AJNR Am J Neuroradiol. 2007 Oct;28(9):1652-8.

41. Kim H, Kim YW, Kim SR, Park IS, Jo KW. Metronidazole-induced encephalopathy in a patient with infectious colitis: a case report. J Med Case Reports. 2011;5:63.

42. Lee SS, Cha SH, Lee SY, Song CJ. Reversible inferior colliculus lesion in metronidazole-induced encephalopathy: magnetic resonance findings on diffusion-weighted and fluid attenuated inversion recovery imaging. J Comput Assist Tomogr. 2009 MarApr;33(2):305-8

43. Omotoso AB, Opadijo OG. Acute encephalopathy associated with metronidazole therapy. Afr J Med Med Sci. 1997 Mar-Jun;26(12):97-8.

44. Park KI, Chung JM, Kim JY. Metronidazole neurotoxicity: sequential neuroaxis involvement. Neurol India. 2011 Jan-Feb; 59(1):104-7.

45. Wienbren M, Perinpanayagam RM, Camba L, Lee CA. Convulsions and encephalopathy in a patient with leukemia after treatment with metronidazole. J Clin Pathol. 1985 Sep;38(9): 1076 .

46. Beloosesky Y, Grosman B, Marmelstein V, Grinblat J. Convulsions induced by metronidazole treatment for Clostridium difficileassociated disease in chronic renal failure. Am J Med Sci. 2000 May;319(5):338-9

47. Frytak S, Moertel CH, Childs DS. Neurologic toxicity associated with high-dose metronidazole therapy. Ann Intern Med. 1978 Mar;88(3):361-2

48. George WL, Kirby BD, Sutter VL, Wheeler LA, Mulligan ME, Finegold SM. Intravenous metronidazole for treatment of infections involving anaerobic bacteria. Antimicrob Agents Chemother. 1982 Mar;21(3):441-9.

49. Halloran TJ. Convulsions associated with high cumulative doses of metronidazole. Drug Intell Clin Pharm. 1982 May;16(5):409.

50. Herreman G, Krainik F, Betous F, Nicolas MO, Mundler B. [Convulsive seizures and polyneuritis in a patient with lupus treated with metronidazole (author's transl)]. Ann Med Interne (Paris). 1981;132(6):398-403

51. Cecil KM, Halsted MJ, Schapiro M, Dinopoulos A, Jones BV. Reversible MR imaging and MR spectroscopy abnormalities in association with metronidazole therapy. J Comput Assist Tomogr. 2002 Nov-Dec;26(6):948-51

52. McGrath NM, Kent-Smith B, Sharp DM. Reversible optic neuropathy due to metronidazole. Clin Experiment Ophthalmol. 2007 Aug;35(6):585-6.

53. Putnam D, Fraunfelder FT, Dreis M. Metronidazole and optic neuritis. Am J Ophthalmol. 1991 Dec 15;112(6):737.

54. Hobson-Webb LD, Roach ES, Donofrio PD. Metronidazole: newly recognized cause of autonomic neuropathy. J Child Neurol. 2006 May;21(5):429-31.

55. Bradley WG, Karlsson IJ, Rassol CG. Metronidazole neuropathy. Br Med J. 1977 Sep 3;2(6087):610-1.

56. Coxon A, Pallis CA. Metronidazole neuropathy. J Neurol Neurosurg Psychiatry. 1976 Apr;39(4):403-5.

57. Gupta BS, Baldwa S, Verma S, Gupta JB, Singhal A. Metronidazole induced neuropathy. Neurol India. 2000 Jun;48(2):192-3.
58. Ramsay ID. Endocrine ophthalmopathy. Br Med J. 1968 Dec 14;4 (5632):706

59. Sarma GR, Kamath V. Acute painful peripheral neuropathy due to metronidazole. Neurol India. 2005 Sep;53(3):372-3.

60. Takeuchi H, Yamada A, Touge T, Miki H, Nishioka M, Hashimoto S. Metronidazole neuropathy: a case report. Jpn J Psychiatry Neurol. 1988 Jun:42(2):291-5.

61. Tan CH, Chen YF, Chen CC, Chao CC, Liou HH, Hsieh ST. Painful neuropathy due to skin denervation after metronidazole-induced neurotoxicity. J Neurol Neurosurg Psychiatry. 2011 Apr;82(4): 462-5.

62. Zivkovic SA, Lacomis D, Giuliani MJ. Sensory neuropathy associated with metronidazole: report of four cases and review of the literature. J Clin Neuromuscul Dis. 2001 Sep;3(1):8-12.

63. Said G, Goasguen J, Laverdant C. [Neuropathy in long term treatment with metronidazole (author's transl)]. Rev Neurol (Paris). 1978 Aug-Sep;134(8-9):515-21.

64. Caylor KB, Cassimatis MK. Metronidazole neurotoxicosis in two cats. J Am Anim Hosp Assoc. 2001 May-Jun;37(3):258-62.

65. Dow SW, LeCouteur RA, Poss ML, Beadleston D. Central nervous system toxicosis associated with metronidazole treatment of dogs: five cases (1984-1987). J Am Vet Med Assoc. 1989 Aug 1; 195(3):365-8

66. Olson EJ, Morales SC, McVey AS, Hayden DW. Putative metronidazole neurotoxicosis in a cat. Vet Pathol. 2005 Sep; 42(5):665-9.

67. Scharer K. [Selective alterations of Purkinje cells in the dog after oral administration of high doses of nitroimidazole derivatives (author's transl)]. Verh Dtsch Ges Pathol. 1972;56:407-10.

68. Placidi GF, Masuoka D, Alcaraz A, Taylor JA, Earle R. Distribution and metabolism of 14C-metronidazole in mice. Arch Int Pharmacodyn Ther. 1970 Nov;188(1):168-79.

69. von Rogulja P, Kovac W, Schmid H. [Metronidazol encephalopathy in rats]. Acta Neuropathol. 1973 Jun 26;25(1):36-45.

70. Loft S, Poulsen HE. Metabolism of metronidazole and antipyrine in hepatocytes isolated from mouse and rat. Xenobiotica. 1990 Feb; 20(2):185-91

71. Rao DN, Harman L, Motten A, Schreiber J, Mason RP. Generation of radical anions of nitrofurantoin, misonidazole, and metronidazole by ascorbate. Arch Biochem Biophys. 1987 Jun; 255(2):419-27.

72. Alston TA. Neurotoxicity of metronidazole. Ann Intern Med. 1985 Jul;103(1): 161

73. Taskapilioglu O, Seferoglu M, Kaygili E, Hakyemez B, Zarifoglu M. Reversible cerebellar toxicity during treatment with ornidazole: the first case report. J Neurol Neurosurg Psychiatry. 2010 Mar;81(3):349-50

74. Chacko J, Pramod K, Sinha S, et al. Clinical, neuroimaging and pathological features of 5-nitroimidazole-induced encephaloneuropathy in two patients: Insights into possible pathogenesis. Neurol India. 2011 Sep-Oct;59(5):743-7.

75. Ludwig E, Csiba A, Magyar T, Szocs G, Graber H. Age-associated pharmacokinetic changes of metronidazole. Int J Clin Pharmacol Ther Toxicol. 1983 Feb;21(2):87-91.

76. Loft S, Egsmose C, Sonne J, Poulsen HE, Dossing M, Andreasen PB. Metronidazole elimination is preserved in the elderly. Hum Exp Toxicol. 1990 May;9(3):155-9.

77. Houghton GW, Dennis MJ, Gabriel R. Pharmacokinetics of metronidazole in patients with varying degrees of renal failure. Br J Clin Pharmacol. 1985 Feb;19(2):203-9.

78. Kuriyama A, Jackson JL, Doi A, Kamiya T. Metronidazole-induced central nervous system toxicity: a systematic review. Clin Neuropharmacol. 2011 Nov-Dec;34(6):241-7. 